\title{
TINJAUAN YURIDIS TERHADAP PERILAKU PENGGUNA HELM DI UNIVERSITAS HALUOLEO
}

\author{
Oleh \\ Ni Putu Sri Widiasih \\ Mahasiswa Pascasarjana Magister Hukum Universitas Airlangga
}

\begin{abstract}
Violations committed by motorists with not using a helmet shows compliance (compliance) are low traffic rules as regulated in section 57 subsection (2) of Act No. 22 of year 2009 about traffic Transport and streets. This type of research is conducted with the normative-legal research efforts are empirical. The research results showed that the factors cause motorists not wearing a helmet at the cross roads and surrounding $\mathrm{A}$ H.E. Mokodompit still in Kecamatan Kambu is a factor of consciousness and behavior, because almost all violations and traffic accidents on the road sekitasrnya and H.E. à Mokodompit that Kecamatan Kambu is still in its primary cause is the rider. These factors gave rise to differences of level of knowledge and/or understanding of the people against the prevailing rules resulted in a disparity that potentially gave rise to traffic problems in particular knowledge of the importance of the benefits the use of helmets for motorbike riders of vehicles that do not wear a helmet, both between road users themselves as well as between road users with apparatus that served to carry out law enforcement on highways, environmental factors contribute active in creating behavior-behavior that deviates. The citizens of the society like the breach of rules that have been set out in the legislation are likely to form a bad or aberrant personality on the individual efforts being done Satlantas Polres Kendari in tackling traffic offences caused by motorcyclists not wearing a helmet at the cross streets of H.E. à Mokodompit is by way of enforcing methods of pre-emptif, is an effort or prevention efforts against irregularities.
\end{abstract}

Keywords: Helmet, Breach Of The User, Traffic

\section{A. PENDAHULUAN}

Manusia sebagai mahluk sosial hidup dalam sebuah tatanan norma-norma sosial yang berlaku, hal ini terjadi karena adanya interaksi manusia yang satu dengan manusia yang lainnya dalam kehidupan bermasyarakat. Masyarakat sebagai wadah tingkah laku hubungan sosial para individu, maka dalam interaksi tersebut masing-masing individu pasti terikat dengan norma-norma dan peraturan-peraturan ataupun kaidah-kaidah yang harus ditaati oleh setiap individu. Kaidah atau peraturan yang mengatur tingkah laku manusia yang lazim disebut hukum.

Perkembangan teknologi saat ini kian pesat, salah satunya di bidang transportasi khususnya kendaraan bermotor. Perkembangan yang pesat itu seharusnya diimbangi dengan sarana lalu lintas jalan raya. Hal ini dengan tujuan untuk mengatasi jumlah kendaraan yang kian hari kian membludak. Semakin membludaknya kendaraan di jalan 
raya sering menimbulkan pelanggaran lalu lintas. Untuk mengatasi masalah tersebut maka diperlukan kaidah-kaidah hukum yang tepat untuk mengatasinya.

Pelanggaran lalu lintas merupakan suatu keadaan dimana terjadi ketidak sesuaian antara aturan dan pelaksanaan. Aturan dalam hal ini yang dimaksud adalah undangundang yang telah ditetapkan oleh negara yang berlaku secara sah, sedangkan masyarakat menjadi pelaksananya. Dalam mengikuti aturan yang tertera dalam pasal-pasal jika tidak sesuai dengan pasal-pasal tersebut, maka disebut pelanggaran lalu lintas. Pelanggaran lalu lintas tidak dapat dibiarkan begitu saja karena bersumber dari suatu pelanggaran tersebut akan timbul kecelakaan lalu lintas, meski juga masih ada faktor lain yang menyebabkannya Helm biasanya digunakan sebagai pelindung kepala untuk berbagai aktivitas pertempuran (militer) atau aktivitas sipil seperti olahraga, pertambangan, atau berkendaraan. Helm dapat memberi perlindungan tambahan pada sebagian dari kepala (bergantung pada strukturnya) dari benda jatuh atau berkecepatan tinggi. Di beberapa negara, helm wajib digunakan bagi pengendara sepeda motor, bahkan ada yang mewajibkannya bagi pengendara sepeda tak bermotor.

Pelanggaran yang dilakukan oleh pengendara motor dengan tidak menggunakan helm menunjukkan kepatuhan (compliance) yang rendah terhadap peraturan lalu-lintas sebagaimana yang diatur pada Pasal 57 Ayat (2) Undang-Undang Nomor 22 Tahun 2009 tentang Lalu Lintas dan Angkutan Jalan, bahwa "Setiap kendaraan bermotor yang dioperasikan di jalan wajib dilengkapi dengan helm Standar Nasional Indonesia”.

Selanjutnya, pada Pasal 106 Ayat (8) dikemukakan bahwa "Setiap orang yang mengemudikan sepeda motor dan penumpang sepeda motor wajib mengenakan helm yang memenuhi Standar Nasional Indonesia".

Berdasarkan hasil observasi penulis pada hari Rabu, 18 Februari 2015 di Kecamatan Kambu, masyarakat dan mahasiswa (i) yang melakukan mobilisasi dari rumah/kost sampai dengan kampus Universitas Halu Oleo atau tempat lain yang masih dalam wilayah Kecamatan Kambu, ada beberapa atau sebagian besar pengendara sepeda motor (kendaraan roda dua) tidak memakai helm seperti yang telah ditetapkan dalam peraturan berlalu lintas. Seharusnya para pengendara mematuhi peraturan undang-undang berlalu 
lintas sebagaimana yang telah ditetapkan, dan kepolisian diharapkan menerapkan peraturan ataupun undang-undang tersebut dengan baik dalam artian sanksi harus diberlakukan dengan asas equality before the law.

Pada kenyataannya terdapat pelanggaran berlalu lintas di Jalan H.E.A Mokodompit menuju Universitas Halu Oleo Kendari yang melanggar peraturan Undang-Undang Nomor 22 Tahun 2009 tentang Lalu Lintas dan Angkutan Jalan, namun tidak ada tindakan sanksi dari kepolisian. Berdasarkan uraian tersebut di atas, maka penulis tertarik untuk mengkaji dan menelaah tentang "Kajian Kriminologis Terhadap Perilaku Pengendara Sepeda Motor Yang Tidak Memakai Helm".

Merujuk pada uraian latar belakang yang dikemukakan di atas, maka ada dua permasalahan pokok yang diajukan, yaitu Faktor-faktor apa penyebab pengendara sepeda motor tidak memakai helm dan Upaya apa yang dilakukan oleh Kepolisian dalam penegakan Undang-Undang Lalu Lintas Nomor 22 Tahun 2009.

\section{B. METODE PENELITIAN}

Tipe penelitian ini dilakukan dengan upaya penelitian hukum normatif-empiris. Tipe penelitian normatif merupakan tipe yang didasarkan pada suatu kajian kriminologi dan berusaha menekankan pada kaidah hukum sesuai dengan aturan Perundang-undangan yang berlaku. Digunakan penelitian empiris bermaksud untuk menemukan dan menganalisis kenyataan-kenyataan yang terjadi di dalam masyarakat khususnya mengenai perilaku pengendara sepeda motor yang tidak memakai helm.

Jenis dan sumber data dalam penelitian ini adalah Data primer yaitu data yang diperoleh secara langsung dari masyarakat dan mahasiswa yang tidak memakai helm pada saat berkendara dengan menggunakan observasi, kuisioner atau angket serta wawancara yang berhubungan dengan pelanggaran lalu lintas terhadap perilaku pengendara sepeda motor yang tidak memakai helm dan faktor-faktor yang mempengaruhi serta upaya-upaya yang dilakukan dan Data sekunder adalah data yang diperoleh dari Kepolisian Resor Kendari dan data sekunder dibutuhkan untuk melengkapi data primer penelitian yang berwujud berupa pendapat-pendapat, dokumen-dokumen resmi, buku-buku, hasil-hasil 
penelitian yang berwujud laporan yang terkait dengan pembahasan dalam penelitian ini dan Peraturan Perundang-undangan yang berhubungan dengan penelitian ini.

Teknik pengumpulan data dalam penelitian ini dilakukan dengan cara Penelitian kepustakaan yaitu penelitian dengan cara menelaah beberapa literature serta bacaanbacaan lain yang berhubungan dengan penelitian ini dan Penelitian lapangan yaitu penelitian yang digunakan dengan cara turun langsung meneliti di lapangan untuk mendapatkan data akurat tentang perilaku pengendara sepeda motor roda dua yang tidak memakai helm dengan melakukan pengamatan (observation), kuisioner atau angket, dan wawancara.

Teknik analisis data yang digunakan dalam penelitian ini adalah analisis kualitatif yang meneliti dan menalaah data, bahan hukum dan segala informasi yang berkenaan dengan pelanggaran berlalu lintas khususnya pengendara sepeda motor roda dua yang tidak memakai helm di lintas wilayah Kecamatan Kambu. Baik yang bersifat umum maupun khusus, data yang diperoleh kemudian diuraikan dalam bentuk uraian secara logis dan sistematis untuk menjawab permasalahan yang ada pada penelitian ini dengan menggunakan bantuan tabek frekuensi dan persentase.

\section{HASIL DAN PEMBAHASAN}

1. Faktor-faktor Penyebab Pengendara Sepeda Motor Roda Dua Yang Tidak Memakai Helm

Terdapat banyak faktor yang mempengaruhi terjadinya pelanggaran lalu lintas di jalan setiap ta hunnya. Faktor tersebut antara lain, adanya paradigma berpikir masyarakat instan di zaman modern, mulai lunturnya sensitivitas dalam berkendara, dan minimnya etika berkendara untuk tertib, saling menghormati, saling menghargai, sehingga mengakibatkan semakin tergerusnya rasa kepemilikan akan sesuatu.

Faktor-faktor di atas mempunyai hubungan kausalitas atau sebab akibat yang saling berkaitan antara satu sama lain. Faktor manusia merupakan penyebab pelanggaran lalu lintas yang paling tinggi karena faktor manusia berkaitan erat dengan etika, tingkah laku, dan cara berkendara di jalan raya. Bentuk pelanggaran itu sendiri merupakan bagian dari 
kelalaian seseorang dalam bertindak dan mengambil keputusan yang tergesa-gesa. Mereka sering mementingkan diri sendiri dari pada mementingkan kepentingan umum.

Melalui angket terbuka di jalan H.E.A Mokodompit, diperoleh gambaran kepatuhan subjek penelitian terhadap peraturan penggunaan helm. Kepatuhan subjek diketahui dari self-report dengan dua pilihan jawaban yaitu, subjek selalu menggunakan helm atau sangat jarang tidak menggunakan helm saat mengendarai sepeda motor, dan subjek selalu atau sangat sering tidak menggunakan helm saat mengendarai sepeda motor. Berbagai alasan yang mendasari kepatuhan subjek mematuhi peraturan penggunaan helm sebagaimana dinyatakan dalam tabel 6.

Tabel 6: Alasan Utama Subjek Mematuhi Peraturan Penggunaan Helm.

\begin{tabular}{|c|c|c|c|}
\hline No. & Alasan & $\begin{array}{c}\text { Frekuen } \\
\text { si }\end{array}$ & $\begin{array}{c}\text { Persentase } \\
\text { (\%) }\end{array}$ \\
\hline 1. & Safety/keamanan & 5 & 3,38 \\
\hline 2. & $\begin{array}{l}\text { Sudah aturan, } \\
\text { kewajiban }\end{array}$ & 34 & 22,97 \\
\hline 3. & $\begin{array}{l}\text { Takut ditilang, takut } \\
\text { ada polisi }\end{array}$ & 23 & 15,54 \\
\hline 4. & Sudah terbiasa & 80 & 54,05 \\
\hline 5. & Terlihat keren & 1 & 0,68 \\
\hline 6. & $\begin{array}{l}\text { Tidak memberikan } \\
\text { alasan }\end{array}$ & 5 & 3,38 \\
\hline & Total & 148 & $100 \%$ \\
\hline
\end{tabular}

Sumber data: Angket Terbuka di Jalan H.E.A Mokodompit April 2015

Berdasarkan data pada tabel 6 di atas diketahui bahwa, tiga alasan utama subjek penelitian mematuhi peraturan penggunaan helm adalah 5 (lima) orang disebabkan alasan keselamatan, terdapat 34 (tiga puluh empat) orang disebabkan karena sudah aturan atau kewajiban, dan 23 (dua puluh tiga) orang disebabkan karena takut ada polisi atau kena tilang. Sementara yang menjadi alasan utama subjek penelitian tidak mematuhi peraturan penggunaan helm adalah 80 (delapan puluh) orang disebabkan karena sudah terbiasa, terdapat 1 (satu) orang disebabkan karena terlihat keren, dan 5 (lima) orang tidak memberikan alasan.

Tabel di atas di peroleh gambaran bahwa penyebab yang dominan adalah karena sudah terbiasa yaitu 80 (delapan puluh) orang atau rata-rata 54,05\%, terdapat 5 (lima) 
orang atau rata-rata 3,38\% tidak memberikan alasan, dan 1 (satu) orang atau rata-rata 0,68 disebabkan karena ingin terlihat keren.

Alasan utama subjek melanggar peraturan penggunaan helm diringkas dalam Tabel 7 sebagai berikut.

Tabel 7: Alasan Utama Subjek Melanggar Peraturan Penggunaan Helm.

\begin{tabular}{|c|l|c|c|}
\hline No. & \multicolumn{1}{|c|}{ Alasan } & Frekuensi & Persentase \\
\hline 1. & $\begin{array}{l}\text { Jarak tempuh } \\
\text { tidak jauh }\end{array}$ & 36 & 58,06 \\
\hline 2. & $\begin{array}{l}\text { Kalau tidak ada } \\
\text { polisi }\end{array}$ & 12 & 19,35 \\
\hline 3. & Merepotkan & 7 & 11,29 \\
\hline 4. & $\begin{array}{l}\text { Tidak nyaman, } \\
\text { panas }\end{array}$ & 6 & 9,68 \\
\hline 5. & Meniru orang lain & 1 & 1,61 \\
\hline & Total & $\mathbf{6 2}$ & $\mathbf{1 0 0}$ \\
\hline
\end{tabular}

Sumber data: Angket Terbuka di Jalan H.E.A Mokodompit April 2015

Data pada Tabel 7 menunjukkan bahwa subjek penelitian tidak mematuhi peraturan penggunaan helm terutama karena jarak tempuh tidak jauh terdapat 36 (tiga puluh enam) orang atau rata-rata 58,06\%, pada saat tidak ada polisi terdapat 12 (dua belas) orang atau rata-rata 19,35\%, dipandang merepotkan terdapat 7 (tujuh) orang atau rata-rata 11,29\%, tidak nyaman/panas terdapat 7 (tujuh) orang atau 9,68\%, dan alasan terakhir karena meniru orang lain terdapat 1 (satu) orang atau rata-rata 1,61\%.

Berdasarkan data yang diperoleh dari pihak kepolisian Resor Kendari dalam kurun waktu 5 (lima) tahun dan melalui angket terbuka di jalan H.E.A Mokodompit yang menunjukkan penyebab pengendara sepeda motor yang tidak memkai helm, faktor yang dominan mempengaruhi penggunaan helm pada pengemudi sepeda motor adalah faktor yang murni berasal dari dalam diri sendiri, yaitu sikap individu terhadap helm sebagai objek sikap dan kontrol diri individu dalam menggunakan helm terkait segala macam konsekuensinya. Di sisi lain, hasil penelitian ini menunjukkan bahwa faktor eksternal seperti pengaruh orang lain.

Penulis memberikan pertanyaan yang sama terhadap seluruh responden, yaitu pertanyaan mengenai faktor-faktor penyebab pengendara sepeda motor tidak memakai helm di lintas jalan H.E.A Mokodompit yang menuju Universitas Halu Oleo dan sekitarnya. 
Dari data-data yang diperoleh oleh Penulis dari wawancara dengan beberapa responden yang tidak memakai helm pada saat mengendarai sepeda motor tersebut di atas, penulis dapat menyimpulkan beberapa faktor yang menyebabkan seseorang melakukan pelanggaran lalu lintas tidak memakai helm pada saat berkendara dengan kendaraan sepeda motor, sebagai berikut:

1. Faktor Kesadaran dan Perilaku

Tidak berlebihan bila dikatakan bahwa, hampir semua pelanggaran dan kecelakaan lalu lintas di jalan H.E.A Mokodompit dan sekitarnya yang masih dalam wilayah Kecamatan Kambu penyebab utamanya adalah pengendara. Penyebab pelanggaran dan kecelakaan lalu lintas paling banyak disebabkan oleh manusia, yang mencakup psikologi manusia sistem indra seperti penglihatan dan pendengaran, dan pengetahuan tentang tata cara lalu lintas.

Penyebab faktor rendahnya kesadaran dan perilaku ini juga dipertegas oleh pernyataan Rudi Sutendi selaku Kanit Patroli Polres Kendari, menyatakan bahwa:

"Dari hasil operasi lalu lintas di jalan memang sampai saat ini faktor manusia masih mendominasi terjadinya pelanggaran lalu lintas bahkan sampai menimbulkan kecelakaan, tentunya hal ini dipengaruhi oleh kurangnya kesadaran, pengetahuan serta lingkungan yang baik serta kesadaran hukum para pengendara sepeda motor khususnya di jalan H.E.A Mokodompit masih sangat kurang". (wawancara tanggal 20 April 2015)

Berdasarkan wawancara di atas, menggambarkan bahwa perilaku pengendara sepeda motor yang tidak memakai helm ditentukan oleh beberapa indikator yang membentuk sikap dan perilakunya di jalan raya. Kesadaran dan perilaku yang membudaya dari pengguna jalan merupakan salah satu faktor utama yang sangat berpengaruh terhadap situasi lalu lintas yang sifatnya akan merugikan diri sendiri.

Etika, sopan santun, toleransi antar pengguna jalan, kematangan dalam pengendalian emosi serta kepedulian pengguna jalan di jalan raya akan menimbulkan sebuah iteraksi yang dapat mewarnai situasi lalu lintas berupa hasil yang positif seperti terciptanya keamanan, keselamatan dan kelancaran lalu lintas maupun dampak negatif 
yang dapat menimbulkan kesemrawutan, kemacetan, pelanggaran dan kecelakaan lalu lintas, sehingga mentalitas pengguna jalan merupakan suatu hal yang fundamental dalam mewujudkan situasi lalu lintas yang baik.

2. Faktor Pemahaman Terhadap Undang-Undang Nomor 22 Tahun 2009 tentang Lalu Lintas dan Angkutan Darat.

Dalam menciptakan dan memelihara keamanan, keselamatan, ketertiban serta kelancaran lalu lintas, telah dilakukan pengaturan yang disesuaikan dengan perkembangan situasi lalu lintas yang ada denganmempertimbangkan perkembangan teknologi di bidang transportasi baik yang berhubungan dengan kendaraan dan dampak lingkungan lainnya dalam bentuk suatu aturan yang tegas dan jelas serta telah melalui roses sosialisai secara bertahap sehingga dapat dijadikan pedoman dalam berinteraksi di jalan raya. Setiap Pengguna jalan wajib memahami setiap aturan yang telah dibakukan secara formal baik dalam bentuk Undang-Undang, Perpu, Peraturan Pemerintah, Perda dan aturan lainnya khususnya Undang-Undang Nomor 22 Tahun 2009 yang mengatur tentang lalu lintas sehingga terdapat satu persepsi dalam pola tindak dan pola pikir dalam berinteraksi di jalan raya.

\section{Faktor lingkungan}

Lingkungan sangat berperan aktif dalam menciptakan perilaku-perilaku yang menyimpang. Seorang individu yang tinggal dalam lingkungan yang baik, sumber daya manusianya bagus, melakukan perbuatan-perbuatan yang baik dan positif akan mempengaruhi kepribadian individu tersebut untuk menjadi baik. Sebaliknya, bila seorang individu hidup dan tinggal dalam lingkungan yang buruk, warga masyarakatnya suka melakukan pelanggaran terhadap aturan yang telah ditetapkan dalam peraturan Perundang-undangan cenderung akan membentuk kepribadian yang buruk atau menyimpang pada diri individu tersebut, seperti yang telah terjadi di lingkungan Jalan H.E.A Mokodompit yang tingkat kepatuhan terhadap aturan lalu lintas sangat kurang. Berdasarkan wawancara penuli dengan Agus Salim selaku anggota Satuan Lalu Lintas (Satlantas) Polres Kendari, menyatakan bahwa: 
"Faktor lingkungan memberikan pengaruh terhadap penyimpangan perilaku pengendara sepeda motor tidak memakai helm di lintas wilayah Kambu khususnya di jalan H.E.A Mokodompit dengan kondisi pelanggaran tersebut yang sering terjadi sehari-hari sehingga menjadi kebiasaan yang lumrah bagi pengendara sepeda motor untuk tidak memakai helm, selain itu karena kurangnya kesadaran pengendara terhadap pentingnya manfaat penggunaan helm dan pengetahuan tentang peraturan lalu lintas. Sehingga membuat perilaku tersebut mempengaruhi pengendara sepeda motor yng melintas di jalan H.E.A mokodompit menuju Universitas Halu Oleo atau tempat tujuan lain mengikuti perilaku tidak memakai helm yang jelas-jelas menyimpang dan melanggar peraturan Undang-Undang Nomor 22 Tahu 2009”. (wawancara 15 Mei 2015)

Wawancara di atas, menggambarkan bahwasanya penyebab kegagalan kepatuhan terhadap peraturan lalu lintas dari segi kondisi lingkungan bisa dijabarkan dalam skenario berikut ini, suatu ketika pengendara tersebut mencoba menggunakan helm, namun keadaan yang ia hadapi adalah bahwa banyak pengendara lain yang ternyata tidak menggunakan helm tidak mendapat sanksi apa-apa, selain itu ia juga merasa tidak nyaman ketika memakai helm karena terasa gerah. Keadaan ini menggambarkan adanya konsekuensi negatif ketika pengendara tersebut berusaha mematuhi peraturan dengan menggunakan helm. Konsekuensi negatif tersebut berasal dari rasa tidak nyaman dan umpan balik sosial yang memperlihatkan bahwa tidak menjadi masalah bila pengendara tidak menggunakan helm

\section{Upaya Kepolisian Dalam Penegakan Undang-Undang Lalu Lintas Nomor 22} Tahun 2009

Upaya yang dilakukan kepolisian dalam mengatasi maslah pelanggaran lalu lintas khususnya pengendara sepeda motor yang tidak memakai helm di lintas jalan H.E.A Mokodompit, dianggap belum maksimal, karena data pelanggaran yang diperoleh dari Polres Kendari khususnya di jalan H.E.A Mokodompit, tidak ada sama sekali penilangan yang di lakukan aparat kepolisian, tetapi pada kenyataan yang terjadi di jalan tersebut 
sering terjadi pelanggaran terhadap Undang-Undang Nomor 22 Tahun 2009 khususnya pengendara sepeda motor yang tidak memakai helm.

Menurut AKP Ida Bagus Sudirgha selaku Kasat Lantas Polres Kendari mengemukakan bahwa:

“Upaya-upaya yang dilakukan jajaran Satlantas Polres Kendari untuk menanggulangi pelanggaran lalu lintas mengguanakan dua upaya yaitu upaya preventif (pencegahan) dan upaya represif (penindakan)." (wawancara tanggal 17 Mei 2015).

Upaya yang dilakukan aparat kepolisian dapat di jelaskan sebagai berikut:

\section{Metode Pre-emptif}

Metode ini merupakan usaha atau upaya-upaya pencegahan terhadap penyimpangan penggunaan helm sejak awal atau sejak dini, yang dilakukan oleh kepolisisan yang mana tindaka ini lebih bersifat psikis atau moril untuk mengajak atau menghimbau kepada masyarakat agar dapat mentaati setiap aturan lalu lintas yang berlaku.

Upaya-upaya ini berupa:

a. Membina hubungan baik dengan tokoh-tokoh masyarakat agar tercipta realisasi perlindungan itu sendiri.

b. Melakukan pembinaan kepada generasi muda dengan mendukung segala kegiatan olahraga dan kegiatan positif lainnya.

c. Membuat selebaran-selebaran mengenai informasi yang dianggap perlu demi mencegah pelanggaran lalulintas.

\section{Metode Preventif}

Dalam rangka menanggulangi terjadinya pelanggaran lalu lintas khususnya pengendara sepeda motor tidak memaki helm di lintas jalan H.E.A Mokodompit dan sekitarnya pihak Satuan Lalu Lintas (Satlantas) Polres Kendari melakukan upaya pencegahan dengan cara memiliki beberapa program yang bersikap edukasi sebagai bagian dari upaya pencegahan (preventif) diantaranya adalah:

a. Polisi Sahabat Anak (Polsana) 
Polsana merupakan kegiatan penanaman tentang kesadaran dan tertib berlalu lintas sejak usia dini. Penanaman disiplin lalu lintas terhadap anak-anak merupakanpenyelamatan anak bangsa. Polsana merupakan program jangka panjang, yang harus selalu ditumbuh kembangkan dan dilakukan secara berkesinambungan. Kegiatan Polsana dapat dilakukan melalui kunjungan maupun open house (anak -anak yang berkunjung ke kantor polisi).

b. Sosialisasi Lintas Universitas

Sosialisasi lintas universitas merupakan kegiatan dari kepolisian yang mengajak kalangan kampus atau akademisi sebagai salah satu stake holder untuk ikut berperan serta dalam menangani masalah lalu lintas. Dalam kegiatan ini tidak hanya sebatas kepada mahasiswa tetapi juga para dosen. Kegiatan sosialisasi ini dapat dilakukan melalui kunjungan, diskusi, seminar, debat publik, serta kampanya keselamatan lalu lintas.

c. Keamanan Berkendara

Keamanan berkendara merupakan kegiatan untuk keselamatan dalam berkendara. Kegiatan ini mencakup pada kegiatan pendidikan dan pelatihan ketrampilan mengendarai kendaraan bermotor, kiat-kiat aman berkendara. Ketrampilan dan keahlian berkendara yang dilatihkan dan diselenggarakan oleh polisi yang bekerjasama dengan sektor bisnis, media dan LSM yang ditujukan baik dari tingkat pelajar, mahasiswa, pengemudi angkutan umum, club otomotif, masyarakat umum atau siapa saja yang peduli terhadap masalah keselamatan berkendara dengan bertujuan meningkatkan kemampuan serta kesadaran berlalu lintas untuk keselamatan para pengguna jalan.

d. Kampanye Keselamatan Lalu lintas

Kampanye keselamatan lalu lintas merupakan kegiatan bersama (kemitraan antara polisi dengan stake holder) sebagai bentuk kegiatan preventif edukatif yang lebih bersifat sosialisasi dalam meningkatkan kedaraan, pengetahuan dan keinginan untuk mentaati peraturan perundang-undangan lalu lintas.

\section{Metode Represif}

Selain menggunakan metode preventif, jajaran satlantas Polres Kendari juga menerapkan metode represif. Pada hakekatnya upaya tersebut merupakan upaya terakhir 
yang ditempuh ketika tindakan edukatif yang terkandung didalam metode preventif tidak dapat menanggulangi permasalahan lalu lintas. Upaya Represif biasanya disertai dengan upaya penerapan paksa. Tindakan represif dilakukan terhadap setiap jenis pelanggaran lalu lintas atau dalam bentuk pelanggaran kasus kecelakaan lalu lintas.

Seperti yang dikatakan AKP Ida Bagus Sudirgha selaku Kepala Satuan Lalu Lintas Polres Kendari, menyatakan bahwa:

"Satlantas Polres Kendari selain menerapkan upaya preventif juga menggunakan upaya represif, hal ini tidak hanya memberikan tujuan pelajaran secara paksa atau hukuman bagi para pelanggar lalu lintas yang tertindak, namun tujuan yang lebih penting adalah membuat jera para pelaku pelanggaran sehingga tidak mengulangi kesalahannya lagi diwaktu mendatang". (wawancara 18 Mei 2015).

\section{PENUTUP}

Berdasarkan rumusan masalah, hasil penelitian, dan pembahasan yang telah diuraikan, maka dapat disimpulkan sebagai berikut. Faktor-faktor penyebab pengendara sepeda motor tidak memakai helm di lintas jalan H.E.A Mokodompit dan sekitarnya yang masih dalam wilayah Kecamatan Kambu adalah Faktor kesadaran dan perilaku, karena hampir semua pelanggaran dan kecelakaan lalu lintas di jalan H.E.A Mokodompit dan sekitasrnya yang masih dalam wilayah Kecamatan Kambu penyebab utamanya adalah pengendara. Penyebab pelanggaran dan kecelakaan lalu lintas paling banyak disebabkan oleh manusia, yang mencakup psikologi manusia sistem indra seperti penglihatan dan pendengaran, dan pengetahuan tentang tata cara lalu lintas. Pelanggaran lalu lintas terkait yang disebabkan oleh pengendara di jalan H.E.A Mokodompit dan sekitarnya disebabkan oleh ingin menghemat waktu dan biaya, ceroboh, tergesa-gesa, ingin cepat sampai tujuan, serta sikap lupa atau lalai dan Faktor pemahaman terhadap Undang-Undang Nomor 22 Tahun 2009 tentang Lalu Lintas dan Angkutan Darat, faktor ini memunculkan perbedaan tingkat pengetahuan dan/atau pemahaman masyarakat terhadap aturan yang berlaku mengakibatkan suatu kesenjangan yang berpotensi memunculkan permasalahan dalam berlalu lintas khususnya pengetahuan pentingnya manfaat penggunaan helm bagi pengendara kendaraan sepeda motor yang tidak memakai helm, baik antar pengguna jalan 
itu sendiri maupun antara pengguna jalan dengan aparat yang bertugas untuk melaksanakan penegakan hukum di jalan raya, Faktor lingkungan sangat berperan aktif dalam menciptakan perilaku-perilaku yang menyimpang. Warga masyarakatnya suka melakukan pelanggaran terhadap aturan yang telah ditetapkan dalam peraturan Perundang-undangan cenderung akan membentuk kepribadian yang buruk atau menyimpang pada diri individu tersebut dan

Upaya-upaya yang dilakukan Satlantas Polres Kendari dalam menanggulangi pelanggaran lalu lintas yang disebabkan oleh pengendara sepeda motor tidak memakai helm di lintas jalan H.E.A Mokodompit ialah dengan cara memberlakukan metode preemptif, merupakan usaha atau upaya-upaya pencegahan terhadap penyimpangan penggunaan helm sejak awal atau sejak dini, yang dilakukan oleh kepolisisan yang mana tindaka ini lebih bersifat psikis atau moril untuk mengajak atau menghimbau kepada masyarakat agar dapat mentaati setiap aturan lalu lintas yang berlaku. Metode preventif(upaya pencegahan) merupakan upaya pencegahan sebelum terjadinya pelanggaran selain itu upaya ini juga lebih bersifat kearah edukatif atau pembelajaran yang dapat memberikan tambahan pengetahuan masyarakat mengenai lalu lintas. Selain menggunakan metode pre-emptif dan metode preventif, jajaran Satlantas Polres Kendari juga menerapkan metode represif, pada hakekatnya metode ini merupakan upaya terakhir yang ditempuh ketika tindakan edukatif yang terkandung didalam upaya preventif tidak dapat menanggulangi permasalahan lalu lintas. Penegakan hukum lalu lintas sebagai bentuk kegiatan represif dilakukan terhadap setiap pemakai jalan yang melakukan pelanggaran terhadap hukum lalu lintas dan angkutan jalan

\section{DAFTAR PUSTAKA}

Indah Sri Utari, 2012, Aliran Dan teori kriminologi, Penerbit Thafa media, Yogyakarta.

John Hagan, 1987, Modern Criminology, crime, Criminal Behavior, and Its Control, Mc Graw Hill Book com, Singapore, p. 164, dalam Paulus Hadisuprapro, 1997.

Lilik Mulyadi, Kajian Kkritis dan analitis terhadap dimensi teori-teori kriminologi dalam perspektif ilmu pengetahuan hokum pidana modern, 
Romli Atmasasmita, Teori dan Kapita Selekta Kriminologi, Penerbit PT Eresco, Bandung, 1992.

Richard Osborne \& Borin Van Loon. 1996. Mengenal Sosiologi ForBeginner. Bandung Rinto Raharjo, 2014, Tertib Berlalu Lintas, Penerbit Shafa Media, Yogyakarta.

Sunarto, Kamanto. 1993. Pengantar Sosiologi. Jakarta: Lembaga Penerbit FE - UI

Soedjono Dirdjosiswojo, 1984, Ruang Lingkup Kriminologi,Remaja Karya, Bandung,

Trias Welas, 2010, Undanag-Undang Lalu Lintas RI No 22 Tahun 2009 Tentang Lalu Lintas Dan Angkuta Jalan, Penerbit New merah, Yogyakarta.

Topo Santoso dan Eva Achjani, 2001, Kriminologi, Penerbit PT Raja Grafindo Persada, Jakarta. 